\title{
Analysis and Design of Restaurant Information System using Unified Modeling Language
}

\author{
Agustinus Fritz Wijaya, Maylani Indah Rakhmawati \\ Faculty of Information Technology, Satya Wacana Christian University \\ Diponegoro Street No. 52 - 60, Salatiga 50711, Central Java, Indonesia \\ agustinus.wijaya@uksw.edu, 682015033@student.uksw.edu
}

\begin{abstract}
This research was done with the aim of facilitating the Admin access to process raw material inventory data which outlets and warehouses are located in different cities. The method used is the SDLC method, which is a method that uses several stages in system development ranging from System Planning, System Analyst, System Design, System Implementation, System Implementation, and System Maintenance. The result of this research is a system that can be accessed by admins to facilitate the work process.

Keyword: Restaurant, Information System, UML
\end{abstract}

\section{INTRODUCTION}

With the development of technology in modern age, the land usage in remote areas is even more widespread and more productive. For instance, forests in the mountains used as toll roads, the hills are decorated in such a way as to become tourist attractions, and also vacant lands are used as stores or housing.

Many people take advantage of this situation to open their businesses in the existing lands. Though taking advantage of this situation in modern era is a good idea, some people do not take advantage of the existing technological advances. The side effect of relying only on human resources is that the business owners will be overwhelmed servicing their customers when their businesses at the peak of their activities and when the existing human resources lack of prerequisite capacities.

It happens to the business of "Hangiri Sushi". This business follows the development of this era by introducing and selling of Japanese food, taking advantage of the surrounding communities who have not known yet about "Sushi". In addition to the enthusiasm of the surrounding community as supporters of the "Hangiri Sushi" business, the business owner of "Hangiri Sushi" in fact also needs human resources.

With the growing popularity of the "Hangiri Sushi" business, the needs of human resources also increase because in this business there are 2 job positions, namely outlet management and warehouse management for checking and recapitulating existing stock of goods.

To simplify the relationship between the Outlet Admin and Warehouse Admin, a system that uses the Waterfall SDLC (System Development Life Cycle) method is created, which is a method that uses several stages in system development, including System Planning, System Analysis, System Design, System Implementation, and System Maintenance.

\section{METHOD}

This research is a qualitative research, which means that data is collected through interviews of the existing data sources. Besides, this reseach also uses the Waterfall SDLC (System Development Life Cycle) Research Method, which is a method that uses several stages in system development.

The stages in system development which is in accordance with SDLC include the following stages:

a. System planning

b. System analysis

c. System design

d. System implementation

e. System maintenance

It can be described in Figure 1. 


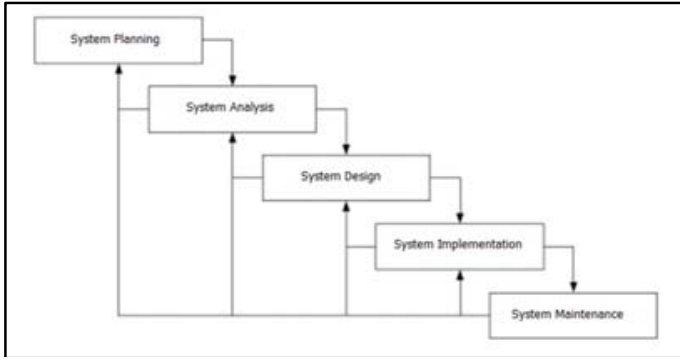

Figure 1. Research Framework Using the SDLC Waterfall Method

1. System Planning

At this stage, the author designs a flow diagram from the results of interview to a system running process. It stars from making of Use case to Activity Diagram.

2. Analysis

At this stage, the author analyzes the needs of outlet and warehouse for websites that can be accessed by the two admins.

3. Design

At the design stage, the author makes a design and flow of website needed, and the author also recaps the data needed on the website.

4. Coding

At this stage, the author begins to create a website and database for the website.

\section{Testing}

The test stage is the final stage of website inspection to see whether or not it runs according to the designed flow.

\section{RESULTS AND DISCUSSION}

This design uses UML (Unified Modeling Language), which is a language to make Use Cases and Activity Diagram.

The Use Case illustrates 2 actors, namely, the Admin Warehouse and Admin Outlet. The Warehouse Admin has all access rights, ranging from adding, deleting and editing of existing goods, and has right to view order data. While, the Admin Outlet only has access rights to add stock and delete data. Can be see at Figure 2.

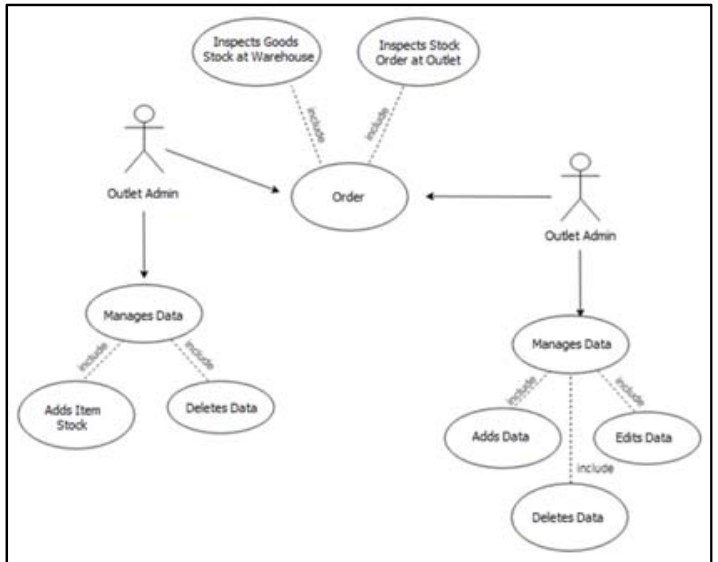

Figure 2. Use Case Diagram

\section{Activity Diagram}

There are two parts in Activity Diagram, namely, the Activity Diagram of Warehouse Admin and the Activity Diagram of Outlet Admin.

The diagram can be described in Figure 3Figure 9.

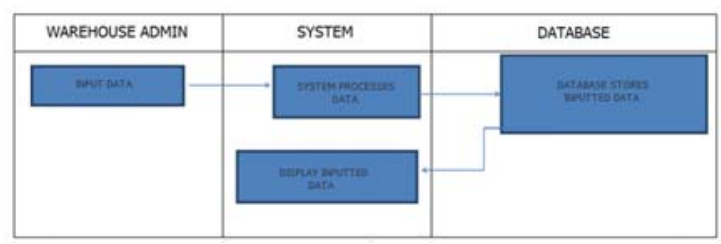

Figure 3. Diagram 1

Diagram 1 illustrates the Activity Diagram of Warehouse Admin whose job is to input data into the system used. In this process, the warehouse admin inputs data and the system directly processes it to enter the database and the result is retrieved in the system.

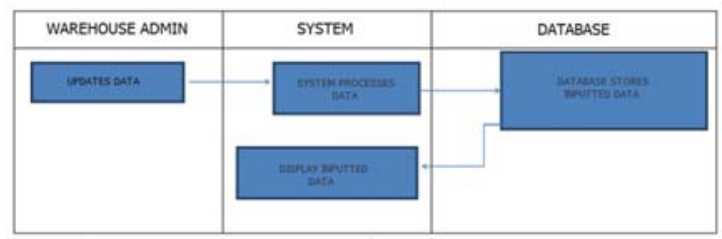

Figure 4. Diagram 2

Diagram 2 illustrates the Activity Diagram of Warehouse Admin whose job is to update or change existing data. In this process, the warehouse admin changes or updates data which then the system directly processes it to enter the database and the result is retrieved in the system. 


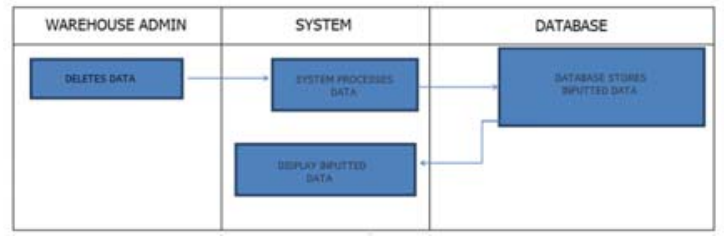

Figure 5. Diagram 3

Diagram 3 illustrates the Activity Diagram of Warehouse Admin whose job is to delete data that is no longer in use or not applicable in the system. In this process, the warehouse admin deletes data and the system immediately processes it to enter the database and the result is retrieved in the system.

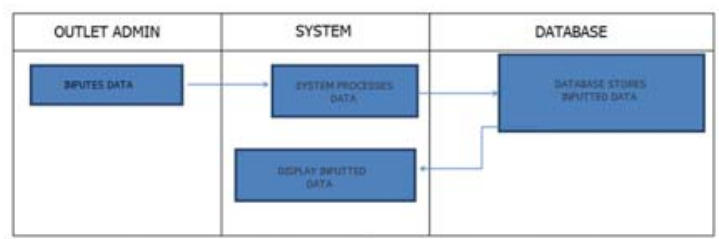

Figure 6. Diagram 4

Diagram 4 illustrates the Activity Diagram of Outlet Admin whose job is only to input data needed to the system. In this process, the outlet admin inputs data and the system directly processes it to enter the database and the result is retrieved in the system.

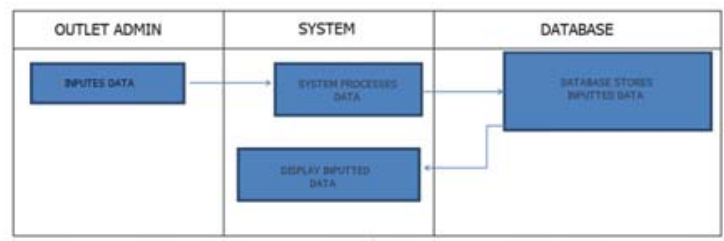

Figure 7. Diagram 5

Diagram 5 illustrates the Activity Diagram of Outlet Admin whose job is to input data into the system. In this process, the admin outlet inputs the name of the item to be ordered and the system directly processes it to enter the database and the result is retrieved in the system.

\begin{tabular}{|c|c|c|}
\hline OUTLET ADMIN & SYSTEM & DATABASE \\
\hline DSUTES ATA & & \\
\hline & & \\
\hline & & \\
\hline & & \\
\hline
\end{tabular}

Figure 8. Diagram 6
Diagram 6 illustrates the Activity Diagram of Outlet Admin whose job is to clear the order list of items to be ordered in the system that is previously entered. In this process, the outlet admin deletes data and the system immediately processes it to enter the database and the result is retrieved in the system.

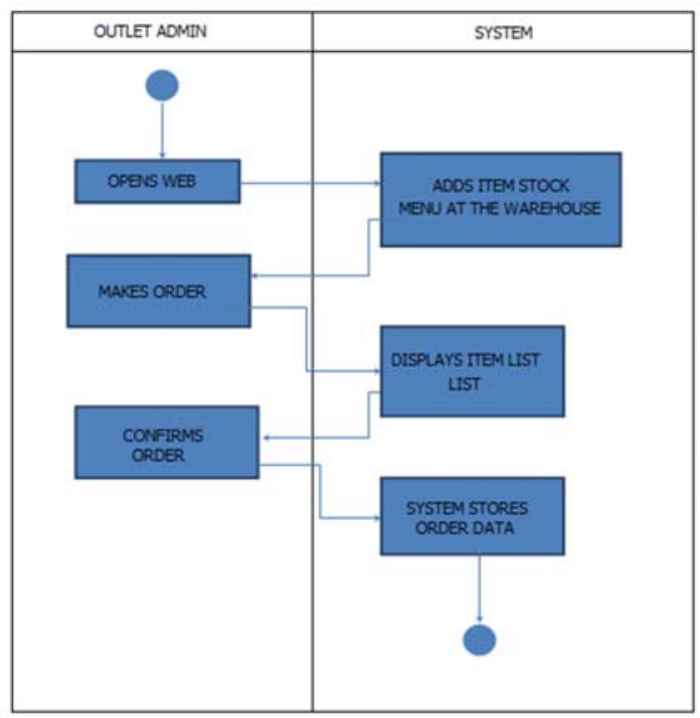

Figure 9. Diagram 7

Diagram 7 illustrates the Activity Diagram of Outlet Admin when ordering items. First, the outlet admin opens the web which then the system will display a stock menu of items in the warehouse. Next, the outlet admin will order the items and then the system will display the order list again to request confirmation to the customer. Finally, after confirming the order, the system will store a list of orders which will be entered in the Warehouse Admin list.

\section{Website User Interface}

Figure 10 is the display of website used by the Warehouse Admin and Admin Outlet.

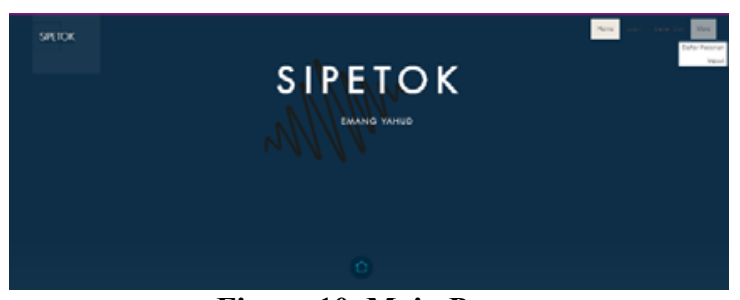

Figure 10. Main Page 
Figure 10 shows the main page of the SIPETOK Website (Stock Order Information System). On this main page there are several sub menus, namely:

a. Home $=$ the main display on the website.

b. $\operatorname{Login}=$ the Admin ID confirmation page before using the website.

c. Stock List $=$ it contains items in the warehouse.

d. More = It displays two sub menus, namely, the Order List sub-menu which lists the items that have been selected by the outlet admin and the Logout sub-menu that used by the admin when the items are ordered on the website.

Figure 11 displays the Login page where the admin must enter the registered email/ID and password. If the admin incorrectly enters the email/ID and password, it will remain on the same page, and if successful the admin will be directed to the Stock List page.

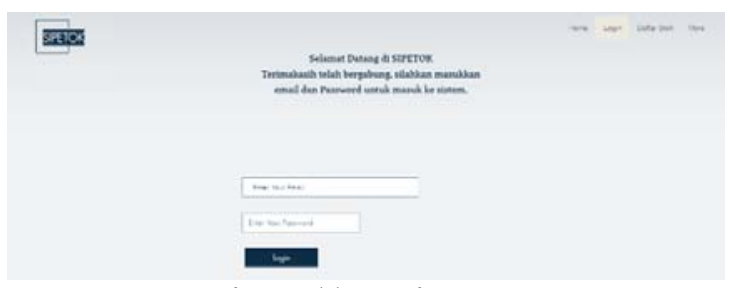

Figure 11. Login Page

Figure 12 displays a list of items available at the warehouse. On this page, the Outlet Admin will choose items that are needed by clicking on the name of the item. The selected name of item will go to the Order List page.

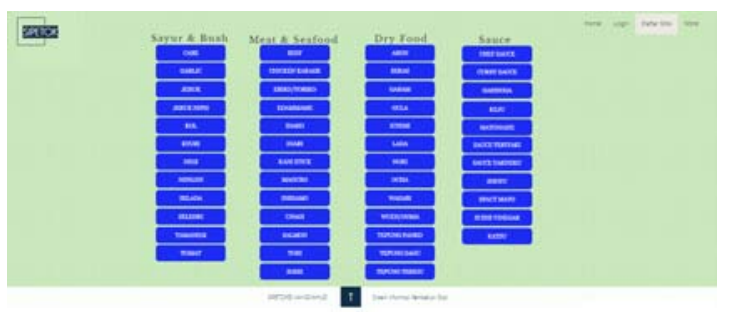

Figure 12. List Item

Figures 13 and 14 are Order List pages that have been selected by the Outlet Admin which the list page also has a button for selecting a number of items to be taken. On this page, there is also a SHOP button which means the shopping process is complete and the selected data will go to the Warehouse Admin database. Thus, the ordering process is finished.

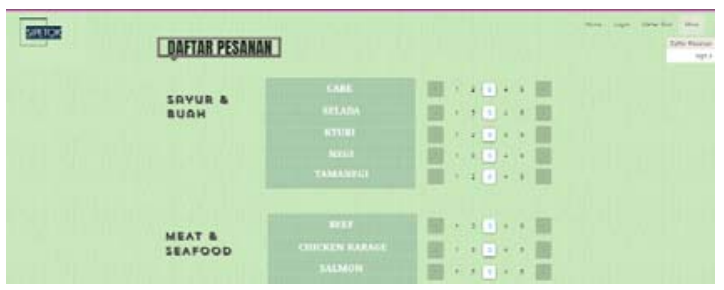

Figure 13. Order List

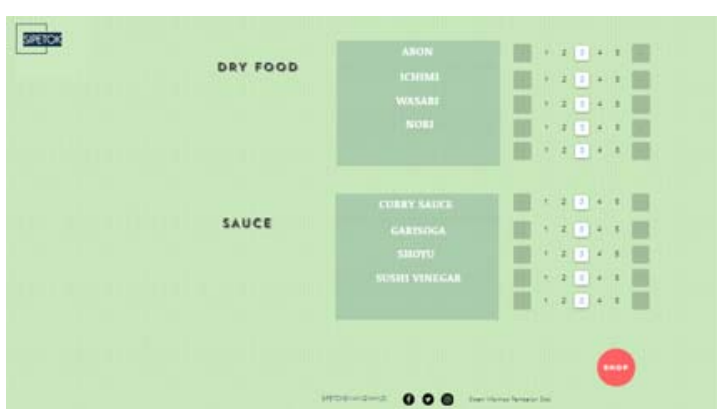

Figure 14. Order List

Figure 15 is the Logout menu display. On this page, there are 2 buttons, namely, Cancel which means the admin will remain on the page and Logout button which means the admin exits the website account and he will be directed to the main page.

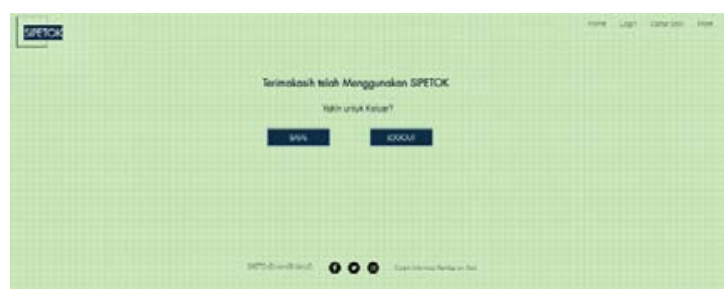

Figure 15. Logout Menu

\section{CONCLUSION}

This system was created to facilitate admin access in processing raw material inventory data. Starting from seeing the list of items that are available in the warehouse up to ordering the items needed for each outlet. It is recommended that this system adds data about the amount of stock available on each item in the warehouse. 


\section{REFERENCES}

[1] Udi, and Firmansyah, Y. (2018). Penerapan Metode SDLC Waterfall dalam Pembuatan Sistem Informasi Akademik. Jurnal Teknologi \& Manajemen Informatika, 4(1), 184-191.

[2] Nugraha, W., Syarif, M., and Dharmawan, W. S. (2018). Penerapan Metode SDLC Waterfall dalam Sistem Informasi Inventori Barang Berbasis Desktop. Jurnal Sistem Informasi Musirawas (Jusim), $3(1)$, 22. Https://Doi.Org/10.32767/Jusim.V3i1.2 46

[3] Irfan, A., Arifitama, B., Studi, P., Informatika, T., Trilogi, U., and Sekolah,
S. I. (2017). Perancangan Sistem Informasi Kelulusan Berdasarkan Tahun Akademik di Yayasan Smp Makna Bakti 1,2. 3(2), 85-94.

[4] Whiteley, D., and Whiteley, D. (2017). System Development Lifecycles. Introduction to Information Systems, $8(2)$, 258-279. Https://Doi.Org/10.1007/978-1-13710325-3_19

[5] Wahyudi, A. (N.D.). Perancangan Sistem Menggunakan Metode SDLC. 1-11.

[6] Rahmad, M. A. (2013). Sistem Informasi Berbasis Web untuk Menunjang Promosi Jasa Foto Pada GBU18Studio. 